\title{
The Development of Natural Science Integrated Instrument Box (KIT) Landslide Props to Improve Student Disaster Preparedness
}

\author{
Nur Ismiyanti Arding ${ }^{1 *}$, Sri Atun ${ }^{2}$ \\ ${ }^{1}$ Science Education, Universitas Negeri Yogyakarta, Sleman, Indonesia \\ ${ }^{2}$ Chemistry Education, Universitas Negeri Yogyakarta, Sleman, Indonesia \\ *Corresponding author. Email: nurismiyanti.2018@student.uny.ac.id
}

\begin{abstract}
Natural disasters in an area can occur anytime and anywhere. An attitude is needed to deal with these disasters. This study aims to determine 1) the feasibility of the The natural science integrated instrument box of landslide props, and 2) the effectiveness of the The natural science integrated instrument box of landslide props to improve the disaster preparedness of students. The research uses 4-D model. The research subjects were students of SMP N 4 Prambanan. Data collection instruments used validation sheets and questionnaires. The feasibility of the The natural science integrated instrument box of landslide props landslide props based on the assessment of the media experts were $92.86 \%$, the material experts were $96.43 \%$ with excellent criteria, the practicality assessment based on the science teacher assessment by $96.43 \%$ with excellent criteria, and the readability results were $82.64 \%$ with excellent criteria. The results analysis of the disaster preparedness questionnaire data showed the scores increased in the experimental class compared to the control class after being treated. So it can be concluded that the The natural science integrated instrument box of landslide props are feasible or valid and effective in increasing disaster preparedness.
\end{abstract}

Keywords: KIT, Landslide Props, Disaster Preparedness.

\section{INTRODUCTION}

Natural science is the knowledge of a way of thinking, a way of investigating, and a body of knowledge [1]-natural science as the body of knowledge that has to do with nature. Science is used not only in the unification of theories and ideas, but science used in knowing the behavior of the universe too, predicting disasters, and discovering new and more sophisticated technologies [2]. The problem often occurs in learning is that educators dominate learning and the lack of interest and curiosity of students to participate. That is because of the reduced knowledge about overcoming obstacles in the implementation of knowledge [3]. The ability of educators needed in implementing strategies to help students in learning, so learning runs appropriately [4]. The use of media is one way that students are interested in learning and can easily understand the material.

Media is a tool that can be used in the learning process [5]. The media serves to provide stimulus to students so that the curiosity of students in a lesson can increase [6], and aids in clarifying the material that will deliver on learning [7]. For example, the natural science integrated instrument box of landslide props. The use of KIT props can increase students' knowledge and experience using real objects in learning, where the natural science integrated instrument box of landslide props can help educators deliver the material in the learning process [8]. Learning Props used in conveying problems that can be captured by students' minds in real conditions [9], because using the learning props students can be directly involved when making observations, so that students' knowledge increases [10].

Disasters are phenomena that occur in this world, which are the center of attention in every country [11]. A disaster is an event that can occur anywhere and at any time and can cause enormous losses. One of the disasters is a landslide. Landslides caused by two factors: natural factors, such as the presence of earthquake vibrations, climate actors, and breaks. Non-natural factors (human activities / activities), for example, cutting on steep slopes and illegal logging [12] [13] [14]. Natural disasters 
have adverse impacts, for example, substantial damage to property [15], material loss, and loss of life [16], while disasters caused by human activities are having negative impacts on ecosystems, property, life, environment, and livelihoods [17]. Damage from disasters can be avoided by focusing on schools in the community, aiming that schools are used as a source of ongoing information and can be used as a place to conduct evaluations [18]. Disaster learning is an essential aspect of carrying out disaster preparedness given to individuals [19], so they can effectively respond and anticipate the effects of events that occur [20]. Disaster material is very needed in learning because it provides knowledge about a disaster because no matter how small the knowledge gained can help if a disaster occurs, we need learning that is given to students to prepare and overcome a disaster.

Knowledge about disaster risk is a significant factor in taking preparedness in reducing the impact of disasters [21]. Encourages students to increase their knowledge and emphasizes students in recognizing potential disasters and disaster risk reduction [22]. Someone's involvement in reducing disaster risk is significant. Involvement in the form of education about disasters, assisting, and efforts in rescue [23]. The effort is a step of preparedness in overcoming an event or danger of natural disasters. Preparedness can reduce losses, damage, and loss of life [24]. Preparedness is an action before a disaster (pre-disaster). The purpose of preparedness is to reduce the impact caused by a disaster or reduce the risk of that impact [25] [26]. If all aspects met, preparedness in facing a disaster could be realized [27]. We can do training to improve preparedness [28], conducting simulations to provide information, for example giving brochures or virtual reality [29], informing triggers of disasters, vulnerable areas, and signs if a disaster will occur [30], as well as through education [31]. The stages in reducing disaster risk are the efforts made before a disaster occurs when a disaster occurs and after a disaster occurs [32].

Based on the existing conditions in the field, there is no media or natural science KIT props integrated with natural disasters, so we need to use media integrated with disasters in learning. For example, the natural science integrated instrument box makes students more aware of the causes of landslides, because students directly participate in assembling and seeing the process of landslides. Therefore, researchers are interested in researching the development of the natural science integrated instrument at the landslides material Method.

\section{METHOD}

This research is development research about the natural science integrated instrument box of landslides (KIT IPA). The subject used was students at SMP Negeri 4 Prambanan at seven classes. The research uses the 4-D model. The procedure consists of 4 stages, i.e., Define
Stage, Design Stage, Develop Stage, and Disseminate Stage [33]. Data collection uses validation sheets and questionnaires. Validation sheet gave to media experts, material experts, and science teachers to assess natural science integrated instrument boxes of landslides (KIT IPA) feasibility. The student response questionnaire gave in a limited trial in the form of a small group of 12 people and Field trials using 45 students - 22 students in the experimental class and 23 students in the control class.

Indicators used in validating IPA KIT products are Conformity between Core Competency and Basic Competence with the material, Suitability of indicators with learning objectives, Clarity of learning objectives, Compatibility of learning objectives with material, Scope and accuracy of activities, Form of natural science integrated instrument box of landslides, Display of integrated instrument box of landslides, Tools and material of integrated instrument box of landslides, According to the characteristics of the contents, Compatability with landslides material, Tool endurance of integrated instrument box of landslides content compatibility, and Practicability of integrated instrument box of landslides.

Indicators used in validating a disaster preparedness questionnaire are Landslide preparedness, Disaster Preparedness Bag, listening to information from various sources, Actions taken before a landslide disaster occurs, Actions taken during a landslide disaster, Actions taken after a land disaster occurs landslides, efforts made to protect, and efforts to reduce disaster risk. The feasibility assessment rubric can be seen in table 1 and the effectiveness rubric can be seen in table 2 .

Table 1. Eligibility Assessment Category

\begin{tabular}{|l|l|}
\hline Score & Category \\
\hline$\overline{\boldsymbol{X}}>3,40$ & Excellent \\
\hline $2,80<\overline{\boldsymbol{X}}<3,40$ & Good \\
\hline $2,20<\overline{\boldsymbol{X}}<2,80$ & Enough \\
\hline $1,60<\overline{\boldsymbol{X}}<2,20$ & Less \\
\hline$\overline{\boldsymbol{X}}<1,60$ & Very Less \\
\hline
\end{tabular}

Table 2. Criteria for Disaster Preparagness

\begin{tabular}{|l|l|}
\hline Interval & Criteria \\
\hline $\mathrm{g} \geq 0,7$ & High \\
\hline $0,3 \leq \mathrm{g}<0,7$ & Medium \\
\hline $\mathrm{g}<0,3$ & Low \\
\hline
\end{tabular}

The method used is quasi-experiment, with Pre-test Post-test Control-Group Design [34]; we can see the design in this study in table 3.

Table 3. Research Design

\begin{tabular}{|l|c|c|c|}
\hline Group & Pre-test & Treatment & Post-test \\
\hline Experimental Class & $\mathrm{O}_{1}$ & $\mathrm{X}$ & $\mathrm{O}_{2}$ \\
\hline Control Class & $\mathrm{O}_{3}$ & $\mathrm{Y}$ & $\mathrm{O}_{4}$ \\
\hline
\end{tabular}


Note:

$\mathrm{X}$ : The Class with the natural science integrated instrument box of landslides (KIT IPA)

Y: The Class with traditional props

O1: Giving questionnaires to the experimental class before being given treatment

O2: Giving a questionnaire to the experimental class after being given treatment

O3: Giving a questionnaire to the control class before being given treatment

O4: Giving a questionnaire to the control class after being given treatment

\section{RESULT AND DISCUSSION}

Evaluation research results from product development carried out using validation sheets and response questionnaires. Validation sheets obtained from media experts, material experts, and science teachers about the natural science integrated natural science box of Landslide props while the response questionnaire obtained from 12 students before the field trial

\subsection{Validation}

The first procedure is validation carried out by media expert lecturers and material experts at FMIPA UNY and science teachers in assessing the appropriateness of the developed natural science integrated instrument box of landslides. The validation result of the media expert showed in Table 4, material experts in Table 4, and Science Teachers in Table 5. indicators that have a score of three. The average percentage is $92.8571 \%$.

Table 5. The result of Science Teacher Validation

\begin{tabular}{|l|c|}
\hline \multicolumn{1}{|c|}{ Indicators } & Score \\
\hline $\begin{array}{l}\text { Form of natural science integrated } \\
\text { instrument box of landslides }\end{array}$ & 4 \\
\hline $\begin{array}{l}\text { Display of integrated instrument box } \\
\text { of landslides }\end{array}$ & 4 \\
\hline $\begin{array}{l}\text { Tools and material of integrated } \\
\text { instrument box of landslides }\end{array}$ & 4 \\
\hline $\begin{array}{l}\text { Practicability of integrated instrument } \\
\text { box of landslides }\end{array}$ & 4 \\
\hline $\begin{array}{l}\text { Tool endurance of integrated } \\
\text { instrument box of landslides }\end{array}$ & 3 \\
\hline content compatibility & 4 \\
\hline Compatability with landslides material & 4 \\
\hline Percentage (\%) & 96,4286 \\
\hline
\end{tabular}

Table 5 shows the results of the validation obtained from media experts, where the scores of four as many as six indicators and one indicator that has a score of three. The average percentage is $96.4286 \%$.

Table 6. Validation Result Natural Science Integrated Instrument Box of lanslides

\begin{tabular}{|l|l|l|}
\hline Validation & Percentage \% & Criteria \\
\hline Media Expert & 96,4286 & Excellent \\
\hline Material Expert & 92,8571 & Excellent \\
\hline Sciente Teacher & 96,4286 & Excellent \\
\hline
\end{tabular}

The results obtained based on the assessment of eligibility were stated to be appropriate for use in the learning process, with the acquisition of the percentage of several validators namely the media expert at $96.4286 \%$, the material expert at $92.8571 \%$ and the

Table 4. Validation Research of Expert

\begin{tabular}{|l|c|l|c|}
\hline \multicolumn{1}{|c|}{ Indicators of Media Expert Validation } & \multicolumn{1}{|c|}{$\begin{array}{c}\text { Results } \\
\text { Results }\end{array}$} & \multicolumn{1}{|c|}{ Score } \\
\hline $\begin{array}{l}\text { Form of natural science integrated } \\
\text { instrument box of landslides }\end{array}$ & 4 & $\begin{array}{l}\text { Conformity between Core Competency } \\
\text { and Basic Competence with the material }\end{array}$ & 4 \\
\hline $\begin{array}{l}\text { Display of integrated instrument box of } \\
\text { landslides }\end{array}$ & 4 & $\begin{array}{l}\text { Suitability of indicators with learning } \\
\text { objectives }\end{array}$ & 4 \\
\hline $\begin{array}{l}\text { Tools and material of integrated } \\
\text { instrument box of landslides }\end{array}$ & 4 & Clarity of learning objectives & 3 \\
\hline $\begin{array}{l}\text { Practicability of integrated instrument } \\
\text { box of landslides }\end{array}$ & 3 & $\begin{array}{l}\text { Compatibility of learning objectives with } \\
\text { material }\end{array}$ & 4 \\
\hline $\begin{array}{l}\text { Tool endurance of integrated instrument } \\
\text { box of landslides content compatibility }\end{array}$ & 4 & Scope and accuracy of activities & 4 \\
\hline $\begin{array}{l}\text { According to the characteristics of the } \\
\text { contents }\end{array}$ & 4 & $\begin{array}{l}\text { According to the characteristics of the } \\
\text { contents }\end{array}$ & 3 \\
\hline Compatability with landslides material & 4 & Compatability with landslides material & 32,8571 \\
\hline Percentage (\%) & 96,429 & Percentage (\%) & 9 \\
\hline
\end{tabular}

Table 4 shows the results of the validation obtained from media experts, where the scores are four as many as six indicators and one indicator with a score of three. So that obtained an average percentage of $96.442 \%$. Validation results of material experts, where the score obtained is four as many as four indicators and three science teacher at $96.4286 \%$, where the criteria of all assessors are outstanding. The development of the KIT IPA landslide props has gone through several revisions, revisions made based on suggestions and input from the validator. Previous research also shows that acceleration 
props were developed and suitable for the learning process, with a value of $75.46 \%$.

\subsection{Preliminary Testing Field}

Preliminary testing field data were obtained from the results of the questionnaire given to grade VII students of SMP Negeri 6 Prambanan. The results showed in Table 7.

Table 7. Preliminary Testing Field Result

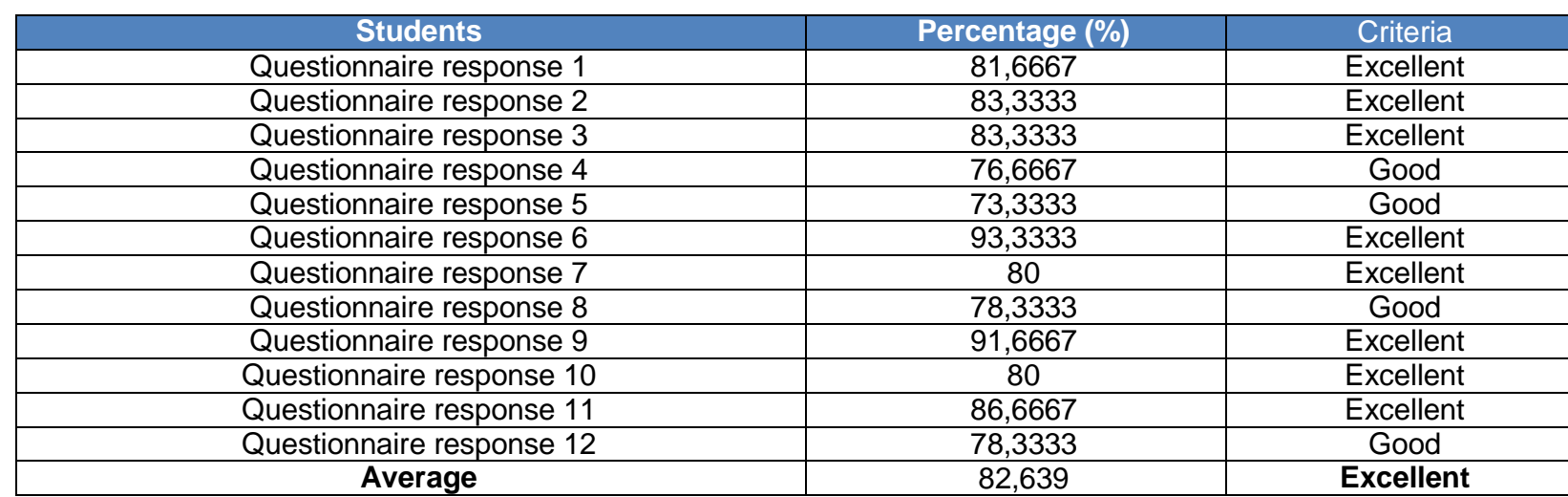

Table 8. Pretest and Posttest Result of Students Disaster Preparedness in Experiment and Control Classes

\begin{tabular}{|c|c|c|c|c|c|c|}
\hline \multirow{2}{*}{ Component } & \multicolumn{3}{|c|}{ Experiment Class } & \multicolumn{3}{c|}{ Control Class } \\
\cline { 2 - 7 } & Pre-test & Post-test & N-gain & Pre-test & Post-test & -gain \\
\hline Average score & 96,91 & 109,77 & 0,41 & 90,30 & 96 & 0,16 \\
\hline Highest Scores & 109 & 119 & 0,58 & 104 & 108 & 0,29 \\
\hline Lowest Score & 88 & 102 & 0,22 & 78 & 82 & 0,07 \\
\hline Middle Score & 96 & 109,5 & 0,40 & 89 & 95 & 0,14 \\
\hline
\end{tabular}

After the validation was carried out, the natural science integrated instrument box of landslides was tried out on preliminary testing to 12 students in SMP N 4 Prambanan. The 12 students are considered sufficient to represent the population in one class. According to [35], the number of good students used in preliminary testing is 10 to 20 students. If the number used is not enough, the results or data obtained from preliminary testing do not describe the population, but if preliminary testing that carried out more than 20 , then the acquisition of data used is less useful in analyzing the evaluation of small groups.

Preliminary testing data are interpreted on a Likert scale, where four people judge in good criteria and nine people who judge in excellent criteria. Therefore, the average percentage obtained based on completing student questionnaires was $82.638 \%$ in excellent criteria.

\subsection{Disaster Preparedness}

Disaster preparedness measured using a questionnaire - data obtained from the results of filling in the students' questionnaire through the pretest and 
Based on the MANOVA test, the results showed significant differences in disaster preparedness in the experimental and control classes. Moreover, from the Test of Between-Subjects Effects' results in Table 9, after being treated, there are significant differences in the disaster preparedness of experimental and control classes, with a value (Sig.) $<0.05$.

The natural science integrated instrument box of landslide props can be said to be effective for increasing disaster preparedness. These results are in line with the previous study [9] that by developing an integrated instrument box hydrostatic, students' understanding of the concept can be improved. [36] stated the results of his research that student learning outcomes can be improved by using the integrated instrument box media application. Research conducted [37] that is by using the integrated instrument box, student learning achievement can increase.

The existence of landslide KIT IPA teaching aids, the disaster preparedness attitude of students develops because students gain knowledge of the actions to be taken in the event of a disaster with the aim of reducing risks such as material loss and casualties. [25] alertness is an action before a disaster (pre-disaster). The goal is that the impact resulting from a disaster can be reduced or reduce the risk of these impacts. The existence of preparedness can reduce losses, damages, and casualties [24]. This is relevant to the research of [38] that the use of props can improve students' disaster awareness attitudes. The results of the study [39] show that students' disaster preparedness can be increased by the use of graphic media. In line with research [40] that giving simulations to students about disaster preparedness can have a positive impact. Research [41] found that student preparedness could be improved by using video and the last research [42] that students' disaster preparedness can be increased by providing disaster preparedness training.

\section{CONCLUSIONS}

The conclusion of this research are: 1 . The results obtained from the assessment of material experts, media experts, science teachers and readability test that have been carried out, it can be concluded that the natural science integrated instrument box of landslide props have been feasible or valid and practical for use in the learning process of junior high school students; 2. The natural science integrated instrument box of landslide props are effective for improving students' disaster preparedness.

\section{ACKNOWLEDGMENTS}

The author would like to thank the headmaster and the teacher of the natural science of SMP Negeri 4 Prambanan and Yogyakarta State University for helping the author so that this study can be completed.

\section{REFERENCES}

[1] E.L. Chiappetta, T.R Koballa, Science Instruction in The Middle and Secondary Schools: Developing Fundamental Knowledge and Skills, United State Of America: Pearson Education Inc, 2010.

[2] J. Trefil, R. Hazen, The sciences: an integrated approach, Hoboken: John Wiley \& Sons, 2010.

[3] R. Spiekermann, S. Kienberger, J. Norton, F. Briones, J. Weichselgartner, The DisasterKnowledge Matrix - Reframing and evaluating the knowledge challenges in disaster risk reduction, International Journal of Disaster Risk Reduction, 2015, vol 13, pp 96-108. DOI: http://dx.doi.org/10.1016/j.ijdrr.2015.05.002

[4] S.N. Shiha, Prabowo, Pengembangan alat peraga percepatan benda untuk menunjang pembelajaran fisika pada materi hukum newton tentang gerak, Jurnal Inovasi Pendidikan Fisika (JIPF), 2014, vol 3(2), pp 180-184

[5] M. Syazali, Pengaruh model pembelajaran creative problem solving maple II terhadap kemampuan pemecahan masalah matematika, Al-Jabar: Jurnal Pendidikan Matematika, 2015, vol 6(1), pp 91-98, DOI: https://doi.org/10.24042/ajpm.v6i1.58

[6] M. Ali, Pengembangan media pembelajaran interaktif Mata kuliah medan elektromagnetik, Jurnal Edukasi@Elektro, 2009, vol 5(1), pp 11-18.

[7] A. Muhson, Pengembangan media pembelajaran berbasis teknologi informasi, Pendidikan Akuntansi Indonesia, 2010, vol VIII(2) pp 1-10. DOI: https://doi.org/10.21831/jpai.v8i2.949

[8] F. Alatas, D. Mulhayatiah, A. Jahrudin, Penggunaan alat peraga uotation timer dan roda fleksibel Untuk meningkatkan kemampuan analisis siswa, Jurnal Penelitian Dan Pembelajaran IPA, 2015, vol 1(1), pp 60-75. DOI: https://doi.org/10.30870/jppi.v1i1.327

[9] Maliasih, Sulhadi, N. Hindarto, Pengembangan alat peraga KIT hidrostatis untuk meningkatkan pemahaman konsep tekanan zat cair pada siswa smp, Unnes Physics Education Journal, 2015, vol 4(3), pp 51-57, DOI: https://doi.org/http://dx.doi.org/10.1089/ars.2015.6 $\underline{320}$

[10] P. Oktaviani, B. Subali, S.S Edie, Pengembangan alat peraga kit optik serbaguna (AP-KOS) untuk meningkatkan keterampilan proses sains, Jurnal Inovasi Pendidikan IPA, 2017, vol 3(2), pp 189 200, DOI: https://doi.org/10.21831/jipi.v3i2.14496 
[11] NEMA, UNDP, Unicaf, OCHA, MSB, UNHCR, OIM, FAO, UNFPA, Emergency preparedness and response (EPR), disaster risk reduction (DRR) capacity assesment (Federal Republic of Nigeroa: National Capacity Asessment Repost), 2012.

[12] A. Mulyono, P. Iqbal, Karakteristik Fisik Tanah Longsoran Di Jalur Transek Liwa-Bukit Kemuning, lampung barat, Jurnal Lingkungan dan Bencana Geologi, 2015, vol 6(1), pp 9-18, DOI: http://dx.doi.org/10.34126/jlbg.v6i1.72

[13] T.R. Wulan, W. Ambarwulan, A.S. Putra, F. Ibrahim, M.D. Putra, D. Maryanto, F. Pinem, E. Maulana, Pemetaan Cepat Kawasan Terdampak Bencana Longsor dan Banjir di Kabupaten Bangli, Provinsi Bali, Majalah Geografi Indonesia, 2017, vol 31(2), pp 44-51, DOI: https://doi.org/10.22146/mgi.26230

[14] D. Puspita, D. Susilowati, E. Kusratmoko, Karakteristik permukiman pada wilayah rawan tanah longsor di desa cibanteng, cianjur, jawa barat, Majalah Geografi Indonesia, 2014, vol 28(1), pp 140-152, DOI: https://doi.org/10.22146/mgi.13073

[15] S. Fuhrmann, L.D. Stone, M.C. Casey, M.D. Curtis, A.L. Doyle, B.D. Earle, D.D. Jones, P. Rodriguez, S,.M. Schermerhorn, Teaching disaster preparedness in geographic education, Journal of Geography, 2008, vol 107, pp 112-120, DOI: https://doi.org/10.1080/00221340802458482

[16] O.E. Ojo, Global Overview of Disaster: Nature; Concept; Impacts and Management Measures, Course paper presented at the 15th edition of MCPDP By NITP and TOPREC, 19th-20th June, 2012 in Ta'al Conference hotel Lafia Nasarawastate-Nigeria, 2013.

[17] M.Z. Wand, I.G.U. Ayuba, B.G. Asika, Needs for Disaster Risks Reduction Education in Nigeria, IOSR Journal of Environmental Science, Toxicology and Food Technology (IOSR-JESTFT), 2015, vol 9(1)(III), pp 43-47, DOI: 10.9790/240209134347.

[18] K. Takahashi, M. Kodama, R. Ernesto, Jr. Gregorio, S. Tomokawa, T. Asakura, J. Waikagul, J. Kobayashi, School Health: An essential strategy in promoting community resilience and preparedness for natural disasters, Global Health Action, 2015, vol $8(1), \quad \mathrm{p} \quad 29106, \quad$ DOI: https://doi.org/10.3402/gha.v8.29106

[19] L.G.H. Midtbust, A. Dyregrov, H.W. Djup, Communicating with children and adolescents about the risk of natural disasters, European Journal Of Psychotraumatology, 2018, vol 9(2), p 1429771,
DOI:

https://doi.org/10.1080/20008198.2018.1429771

[20] K. Kitagawa, J. Preston, C. Chadderton, Preparing for disaster: a comparative analysis of education for critical infrastructure collapse, of Risk Research, 2017, vol 20(11), pp 1450-1465, DOI: https://doi.org/10.1080/13669877.2016.1178661

[21] D. Hidayati, H. Permana, K. Pribadi, F. Ismail, K. Meyers, Widayatun, T. Handayani, Bustami, D.A. Daliyo, Fitranita, L. Nagib, Ngadi, Y. Kumoro, I. Rafliana, A. Argo, Kajian kesiapsiagaan masyarakat dalam mengatasi bencana gempa bumi dan tsunami, Jakarta: LIPIUNECO_ISDR, 2006.

[22] Kagawa F and Selby D, Ready for the storm: education for disaster risk reduction and climate change adaptation and mitigation 1, Journal of Education for Sustainable Development, 2012, vol 6(20), pp 207-217.

[23] E.A. Newnham, J. Tearne, X. Gao, B. Guragain, F. Jiao, L. Ghimire, J. Leaning, Tailoring disaster risk reduction for adolescents: Qualitative perspectives from China and Nepal, International Journal of Disaster Risk Reduction, 2019, pp 34 - 337-345

[24] S.G. Purnama, Modul manajemen bencana, Denpasar: Fakultas Kedokteran Universitas Udayana Program Studi Kesehatan Masyarakat, 2017.

[25] M.K. Rañeses, A. Chang-Richards, J. Richards, J. Bubb, Measuring the level of disaster preparedness in Auckland, Procedia Engineering, 2018, vol 212, $\mathrm{pp}$ 419-426,

DOI:

https://doi.org/10.1016/j.proeng.2018.01.054

[26] M. Widjanarko, U. Minnafiah, Pengaruh pendidikan bencana pada perilaku kesiapsiagaan siswa, Jurnal Ecopsy, 2018, vol 5(1), pp 1-7.

[27] S.A. Fitrissani, S. Milfayetty, M. Dirhamsyah, Pengembangan Modul Kesiapsiagaan gempa Bumi pada Materi Geografi untuk meningkatkan Kesiapsiagaan siswa SMAN 5 Banda Aceh, Jurnal Ilmiah Kebencanaan: Pascasarjana Universitas Syiah Kuala, 2014, vol 1(1), pp 9-16.

[28] A.H. S. Direja, S. Wulan, Faktor-Faktor yang Berhubungan dengan Kesiapsiagaan Tenaga Kesehatan dalam Menghadapi Bencana Gempabumi dan Tsunami, Journal Dialog Penanggulangan Bencana BNPB, 2018, vol 9(2), pp 102-115.

[29] S. Appleby-Arnold, N. Brockdorff, I. Jakovljev, S. Zdravković, Applying cultural values to encourage disaster preparedness: Lessons from a low-hazard country, International Journal of Disaster Risk 
Reduction, 2018, vol 31, pp 37-44, DOI: https://doi.org/10.1016/j.ijdrr.2018.04.015

[30] BNPB, Buku saku tanggap tangkas tangguh menghadapi bencana, Jakarta: Badan Nasional Penanggulangan Bencana, 2018.

[31] J. Kwesi-Buor, D. Menachof, R.HA. Talas, Scenario analysis and disaster preparedness for port and maritime logistics risk management, Accident Analysis \& Prevention, 2016, DOI: http://dx.doi.org/10.1016/j.aap.2016.07.013

[32] BNPB, Buku saku tanggap tangkas tangguh menghadapi bencana, Jakarta: Badan Nasional Penanggulangan Bencana, 2012.

[33] S. Thiagarajan, D.S. Semmel, M.I. Semmel, Instructional development for training theacher of exceptional children, Bloomington Indiana: Indiana University, 1974.

[34] D. Chawla, N. Sondhi, Research methodology concepts and cases, second edition, India: House Pvt Ltd, 2015.

[35] I. Restiyowati, I.G.M. Sanjaya, Pengembangan ebook interaktif pada materi kimia semester genap kelas xi sma, Unesa Journal of Chemical Education, 2012, vol 1(1), pp 130-135

[36] D. Sunggu, Peningkatan hasil belajar organ pencernaan makanan pada manusia melalui media kit ipa murid kelas iv sdn 169 sarong kabupaten tanah toraja, Jurnal Pemikiran dan Pengembangan Pembelajaran, 2019, vol 1(3), pp 151-162.
[37] L. Indayani, Peningkatan prestasi belajar peserta didik media kit ipa di smp negeri 10 probolinggo, Jurnal Kebijakan dan Pengembangan Pendidikan, 2015, vol 3(1), pp 54-60.

[38] H. Mudzakiroh, E. Hariyono, Pengembangan Alat Peraga Alarm Gempa Bumi Sebagai Media Pembelajaran Materi Gelombang Kelas XI di SMA Negeri 1 Panggul, Trenggalek, Inovasi Pendidikan Fisika, 2013, vol 2(3), pp 11-18.

[39] A. Purwani, L. Fridani, Fahrurrozi, Pengembangan media grafis untuk meningkatkan siaga bencana banjir, Jurnal Obsesi: Jurnal Pendidikan Anak Usia Dini, 2019, vol 3(1), pp 55-67.

[40] F.N. Indiasari, Pengaruh pemberian metode simulasi siaga bencana gempa bumi terhadap kesiapsiagaan anak di Yogyakarta, Jurnal Keperawatan Soedirman, 2016, vol 11(3), pp1-7.

[41] F. Wulandari, Pengaruh media video terhadap kesiapsiagaan siswa dalam menghadapi bencana gempa bumi di sma negeri 1 gantiwarno, klaten, Jurnal Pendidikan Ilmu Pengetahuan Sosial Indonesia, 2018, vol 3(2), pp 18-20

[42] R. Daud, S.A. Sari, S. Milfayetty, Dirhamsyah, Penerapan pelatihan siaga bencana dalam meningkatkan pengetahuan, sikap, dan tindakan komunitas sma negeri 5 banda aceh, Jurnal Ilmiah Kebencanaan (JIKA), 2014, vol 1(1), pp 26-34. 